\title{
Outsourcing the information technology function: Perspectives from employees
}

\author{
M. Sadiq Sohail \\ Department of Management and Marketing, \\ College of Industrial Management, \\ King Fahd University of Petroleum and Minerals \\ PO Box 210, Dhahran 31261, Saudi Arabia \\ E-mail: ssohail@kfupm.edu.sa
}

Received October 2010

\begin{abstract}
The purpose of this paper is to investigate human aspects of outsourcing and its impact on employees and organizational performance. This study is based on a questionnaire survey conducted in Saudi Arabia. Based on an extensive review of literature, the paper uses empirical research to analyse employees' attitude towards outsourcing. Results based on the analysis of data from 178 firms in Saudi Arabia indicate that employees largely perceive outsourcing as a positive development. Limitations of this paper relate to the relatively small size of the sample. Findings have several practical implications for small start-up firms and even larger firms that are deciding to outsource IT function in the Arabian Gulf region. The results provide managers with evidence supporting the benefits of IT outsourcing. This paper makes a valuable contribution given the fact that there are only a limited number of comprehensive studies dealing with the assessment of employees' attitude towards outsourcing IT functions. Most previous studies have looked into business aspects of outsourcing in IT function.
\end{abstract}

*To whom all correspondence should be addressed.

\section{Introduction}

As industries become competitive, firms have been using their core competencies to gain competitive advantage. Outsourcing has become one of the strategies adopted by businesses to manage their Information systems (Gonzalez, Gasco \& Llopis, 2006). As a result of this strategy, a major trend in evidence is the outsourcing of various organizational functions. In the domain of information systems, outsourcing has become a viable strategic alternative to acquire and managing costly as well as complex information technology (hereafter called IT) (Grover, Cheon \& Teng, 1994). Studies have shown that organizations have been outsourcing IT functions since the early 1960s (Due, 1992; Lacity, 1992). From data processing in the $60 \mathrm{~s}$, modern day IT outsourcing has made significant strides with a variety of business processes being outsourced. Given the popularity and increasing usage of IT outsourcing, a number of studies have been undertaken to study this phenomena. Through a review of extant literature, two broad tendencies are observed. Firstly, a vast majority of existing literature on IT/IS (information systems) outsourcing deals with the business aspects such as, rationale for outsourcing, vendor selection process, benefits to firms, extent of usage, contract negotiation and extent of commitment. Secondly, it is evident that research in this area has largely focused in developed economies.
Amidst this backdrop, the aim of this research is to investigate into the human aspects of outsourcing. While managers involved in decision making to outsource argue that there is more effective utilization of firm's human resources, studies have also pointed out that with outsourcing leading to possible elimination of employees in respective field, and it is likely to cause an adverse impact on staff morale. In fact, in the context of IT, firms cannot expect to achieve competitive advantage by acquiring sophisticated IT equipment; this comes through the skilled management of people (Sohal \& Ng, 1998).

Information technology outsourcing, which is considered a "growing phenomenon in developed economies" (Willcocks, Fitzgerald \& Fenny, 1995) has received scholarly attention, but much of this research has focused on developed nations of the West. Recent research on IS outsourcing has focused on factors driving the outsourcing decision (e.g. Aubert, Patry \& Rivard, 2004; Yang \& Huang, 2000), companies' knowledge sharing success (e.g., Lee, 2001), the business impact of IS outsourcing (e.g. Han, Lee \& Seo, 2008), risks of IS outsourcing (e.g., Beasley, Bradford \& Pagach, 2004), the effect of IS outsourcing announcements on firm performance (e.g., Han et al., 2008) and firm market value (e.g. Oh, Gallivan \& Kim, 2006), and the impact of firm characteristics and management's explicit strategic intent on the market value of the firm (Beasley, Bradford \& Dehning, 2009). 
This study focuses on a developing nation in the Middle East region. Saudi Arabia is at the heart of the second fastest growing market (at an average $17-25 \%$ pa). Saudi Arabia is a key member of the Gulf Cooperation Council (GCC), the most powerful trade group in the Middle East.

Since its accession to the World Trade Organization (WTO), Saudi Arabia has seen numerous economic reforms. Saudi Arabia has been working towards removing protectionist barriers; place ceilings on tariffs; further open key services sectors to foreign participation and improve intellectual property rights protection. These changes provide immense opportunities even to global IT service providers to make a presence in the market.

\section{Literature review}

\section{Information technology outsourcing}

Outsourcing is defined as having work that was formerly done inside the organization performed by an external organization. The use of outsourcing is becoming more sophisticated; more organizations are outsourcing business processes. One of such areas commonly outsourced now is IT/IS (for the purpose of this study both these terms are used interchangeably).

Information technology (IT) outsourcing is a process by which transfer of property or decision rights in varying degrees over the IT infrastructure takes place from the user organization to an external organization (Barthelemy \& Geyer, 2004).Time sharing for instance, which involves purchasing computer time, was very popular in the 1960s and 1970s. From the mid-1980s on however, a new type of IT outsourcing was initiated (Barthelemy \& Geyer, 2004).

IT outsourcing is broadly defined as a process undertaken by a firm to contract-out or to sell the organization's IT assets, staff and/or activities to a third party supplier, who in exchange provides and manages IT assets and services for monetary return over an agreed period of time (Kern, Kreijger \& Willcocks, 2002). A few other studies have defined outsourcing as an act of subcontracting a part or all of a firm's IT function to one or more external vendors (Cheon, Grover \& Teng, 1995; Geibstein, 2002; Loh \& Venkatraman, 1992; Sengupta \& Zviran, 1997).

As said earlier, firms have been using IT outsourcing since the early 1960s (Due, 1992; Lacity, 1992). In 1963, Perot's electronic data systems (EDS) were performing data processing services for Frito-Lay and Blue Cross (Mason, 1990). Current IT outsourcing has changed significantly since these earlier arrangements. The differences relate to the operational, technical, and financial sophistication of outsourcing vendors and the flexibility of their offerings (Bhattacherjee, Tung \& Pathak, 2004). A significant approach in current practices towards IT outsourcing from the past is that outsourcing is no longer restricted to small and medium-sized firms that do not possess their own IT infrastructure, but large corporations also resort to outsourcing (Mahmood, Hall \& Swanberg, 2001). Firms are also reportedly outsourcing an increasingly large range and depth of services that also involves transfer of personnel and equipment to the outsourcing firm (Mahmood et al., 2001). Such variances have contributed to the IT outsourcing function gaining popularity Other reasons for the popularity of outsourcing include: decision to outsource represents a shift in business strategy that is aimed at refocusing on core competences, as well as on an uncertainty about the value of IT (Smith \& Kumar, 2004).

A review of literature on outsourcing literature reveals that most studies have focused on examining two broad areas. Firstly, studies have attempted to investigate on the reasons that compel firms to engage in different types of outsourcing arrangements in alternative industry settings. Secondly, studies have reported on the key determinants affecting the overall performance of the outsourcing process.

\section{Rationales for IT outsourcing}

IT outsourcing has received a lot of attention from the managerial literature. The academic literature has also devoted attention to understand the rationale of IT outsourcing (Barthelemy \& Geyer, 2004). Researchers have studied the impact of various determinants on IT outsourcing decisions These include an attempt to understand and close the gap between actual and desired IT performance; transaction costs and production costs considerations; and interactions between economic and institutional factors in IT outsourcing (Barthelemy \& Geyer, 2004).

Gleaning through literature, a number of reasons for IT outsourcing can be identified. The purported primary benefit of outsourcing is cost benefit (Khosrowpour et. al., 1996). The significance of the cost savings from outsourcing is so great that, a study recommends that almost all organizations, both public and private, should consider outsourcing as an opportunity for savings (Gonzales et al., 2006). Cost reduction is the most commonly cited reason for a firm's outsourcing decision (Lacity \& Willcocks, 1998; Loh \& Venkatraman, 1992; McFarlan \& Nolan, 1995). Regarding the management of outsourced IT activities, recent researchers have focused on the impact of partnerships on outsourcing success. The impact of transaction cost considerations on the terms and management of the contract has also been investigated (Adeleye, Annansingh \& Nunes, 2004).

IT outsourcing cut costs by as much as 10 per cent to 50 per cent (Lacity \& Hirschheim, 1993). This is because a firm now has expertise and up-to-date software and hardware facilities, which enables a service provider to maintain and run an application more cheaply than doing it in-house (Lacity \& Wilicocks, 1998; McFarlan \& Nolan, 1995).

Cost reduction is not the only rationale behind all IT outsourcing decisions. The driving forces for IT outsourcing is the need to focus on core activities and technical consideration, in addition to cost reduction (Costa, 2001). Firms concentrate on their core activities and exploit competencies based on their experience and knowledge, contracting out activities in which they are less competent (Beaumont \& Costa, 2002). 
In addition, outsourcing IT functions can also enable companies to lower the inherent risk found with spending large amounts of money on technology (Mahmood et al., 2001). Outsourcing can reduce such risks in two ways. First, the risk of investing in the wrong hardware and having no recourse to recover the money is reduced. Second, the risk of system development overruns is assumed by the vendor rather than the client (Smith \& Kumar, 2004).

However, in contrast to these studies another study examining offshore outsourcing of information technology services in the wake of globalization concludes that in spite of strategic advantages and cost benefits, outsourcing relationships also involve risks, for both the client, as well as the service provider. Using a case based approach; these authors conclude that three broad categories of service provider risks are prevalent, namely macroeconomic, relationship specific and project specific (Aundhe \& Mathew, 2009).

\section{Employee attitude on IT outsourcing}

Most studies on outsourcing pay little attention to the human aspects of outsourcing (Khosrowpour et al., 1996). Considering the fact that one of the largest costs and complications of running an organization's own information systems department is that of hiring and retaining qualified information systems professionals, any reduction in the these professionals may result to significant lowering of payroll. When a firm outsources its IT function, there is an inverse relationship between outsourcing and the number of employees (Gonzales, 2006). This is a major source of concern to a firm because no matter how well the outsourcing process is handled, it is inevitable that some employees will be negatively impacted.

Few research studies conducted on human resource issues of IT outsourcing have indicated that employees are affected by outsourcing. Yet, little has been done to investigate the attitudes and perceptions of the outsourced employees or to determine ways to ease their transition (Kessler, Coyle-Shapiro \& Purcell, 1999; Due, 1992; Khosrowpour et al., 1996; Benson, 1998; Logan, Faught \& Ganster, 2004). One of a few studies on employee concerns found that contrary to what managers might predict, a satisfied and involved workforce could prove to be the most difficult to assimilate into the new organizational structure resulted by outsourcing (Logan et al., 2004).

Outsourcing may create great chaos; strikes have been initiated by workers subjected to outsourcing (Wilcocks et al., 1995). Additionally, the adverse effect of outsourcing on employees may result in less than optimal performance (Laribee \& Michaels-Barr, 1994). As with any rumour that deals with one's job security and well-being, the potential for an outsourcing deal will probably affect the productivity of the information systems group (Lacity, Khan \& Willcocks, 2009). This lag in productivity will last as long as unsubstantiated rumours abound and will probably not get back to normal levels until some answers come forth from a credible source. For this reason, many organizations that had previously outsourced had to bring back an outsourced activity in-house (Lacity et al., 2009).

Barthelemy and Geyer (2004) maintained that outsourcing vendors' reputations are not the best with information systems professionals; many IT executives see these firms as a threat to their security. When employees learn that outsourcing is being considered, they naturally question the loyalty of the employer resulting in a drop in morale. In some instances, the IT professionals may view the consideration of outsourcing as an underestimation of their abilities or a lack of confidence. This can be demoralizing to a staff and contribute to a mass exodus of talent before the outsourcing decision has even been made (Barthelemy $\&$ Geyer, 2004). Transitioned employees who survive the outsourcing activities may remain insecure about how long the vendor will keep them around or what their career potential is with the new company (Mann, 2003). Moreover, by changing the employment relations in a firm, outsourcing alters the relationship to their employees and in the most severe case, the employees are terminated (Logan et al., 2004). Employers certainly do not want to needlessly upset their employees.

While most studies show that employee perceptions and prior job attitudes can have negative effects due to outsourcing, a few studies have reported contrary findings. In some instances, employees may find the new work environment to be stimulating and challenging (Benson, 1998). Kessler et al. (1999) found that outsourced employees maintain their commitment to the host company and that this commitment was stronger than their commitment to the new employer.

Considering all of the above, firms that do choose to outsource should carefully consider their treatment as well as the vendor's treatment of the professionals involved (Khosrowpour et al., 1996). It is important for managers to understand employee attitudes towards outsourcing so they can deal effectively with problems during the transition (Logan et al., 2004). For instance, management could shape employee attitudes toward outsourcing decisions and help them to understand the positive aspects (Khosrowpour et al., 1996).

\section{Research framework}

In line with the conceptualization of this study, a research framework was specifically developed. The framework presented in Figure 1 focuses on the following areas

- $\quad$ individual factors affecting employees attitude towards IT outsourcing services;

- organizatioal factors affecting employees attitude towards IT outsourcing services;

- factors relating to vendor company that may affect employees attitude towards IT outsourcing services; 


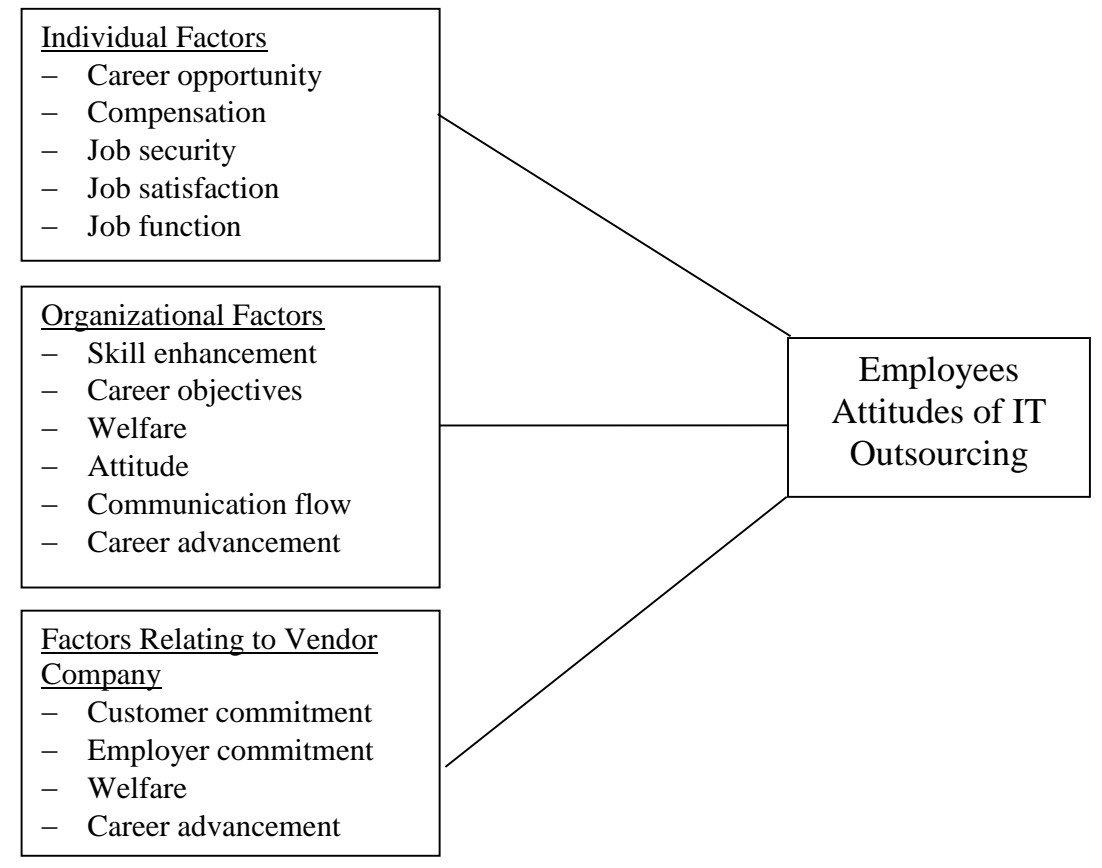

Figure 1: The research framework

\section{Methodology and data collection}

\section{Methodology}

A survey instrument was developed reflecting the framework depicted in Figure 1. In the first part of the instrument, a screening question was asked on whether the firm outsourced its IT functions are not. Those who responded in the affirmative were asked to proceed to complete the survey, while answering in the negative were required to terminate. Other questions in this section comprised questions to gather the demographic information as well as question intended to capture information on feelings and attitude towards outsourcing and job displacements, if any. The second part of the instrument related to the framework of the research. Mail survey was conducted. The target population included all firms in Saudi Arabia, which had significant IT activities. The sampling frame comprised of all companies of different size and industry doing business in Saudi Arabia.

\section{Data collection}

The target population included all firms in Saudi Arabia, which outsourced IT/IS function. The target respondents were senior employees in charge of performing IT function. Primary data collection poses numerous challenges to researchers in Saudi Arabia (Sohail \& Al-Abdali, 2005). Due to the closed nature of the Saudi society and business firms, and a general apathy to unsolicited surveys, repeated waves of reminders and call-backs were undertaken. Further, due to a preference for formality, research assistants were engaged to make personal visits and to distribute/administer the survey questionnaire to randomly selected firms that had consented to participate.

A total of 1000 questionnaires were randomly distributed. Of these, 178 completed questionnaires were received, representing 17.8 per cent response rate, which compares which compares favourably with the response rate of $14.6 \%$ (Khosrowpour et al., 1996).

\section{Study findings and implications}

\section{Survey responses and profile of respondents}

Of the 178 respondents, 63 per cent of them worked in general IS functional areas. The remaining were specialised in functional areas that are IT related, about 20 per cent as system development professionals and 12 per cent in computer operations. Respondents belonged to diverse industries as indicated in the Table 1. In terms of educational qualifications, a majority of them, that is 56 per cent, were bachelor degree holders and 40 per cent had masters or doctoral degrees. As for work experience, 40 per cent each had worked for less than 5 years or between 5 to 10 years. About 13 per cent had been working for between 11 to 20 years, while the remaining 7 per cent had a work experience of more than 20 years.

As for the size of firm, most of them belonged had large number of employees. The sample also comprised of 'medium' and 'small' sized firms ( 25 and 8 per cent respectively). The samples were also almost equally drawn from the three major province of Saudi Arabia. 
Table 1: Demographic profile of respondents

\begin{tabular}{|c|c|c|}
\hline & Frequency & Valid Percent \\
\hline \multicolumn{3}{|l|}{ Functional Area } \\
\hline System Development & 35 & 19,7 \\
\hline Academic & 8 & 4,5 \\
\hline Computer Operations & 22 & 12,4 \\
\hline General IS Functions & 113 & 63,4 \\
\hline \multicolumn{3}{|l|}{ Industry } \\
\hline Manufacturing & 34 & 19 \\
\hline Financial & 28 & 16 \\
\hline Government and Utilities & 35 & 20 \\
\hline IT\IS Related & 35 & 20 \\
\hline Other & 46 & 26 \\
\hline \multicolumn{3}{|c|}{ Total Employees in Company } \\
\hline $1-100$ & 15 & 8 \\
\hline $101-500$ & 44 & 25 \\
\hline Over 500 & 119 & 67 \\
\hline \multicolumn{3}{|l|}{ Highest Degree } \\
\hline High school & 5 & 2,8 \\
\hline Bachelor's Degree & 100 & 56,2 \\
\hline Master's Degree & 66 & 37,1 \\
\hline Doctorate Degree & 5 & 2,8 \\
\hline Other & 2 & 1,1 \\
\hline \multicolumn{3}{|c|}{ Years in Information Systems Profession } \\
\hline Less than 5 & 72 & 40,4 \\
\hline $5-10$ & 70 & 39,3 \\
\hline $11-20$ & 23 & 12,9 \\
\hline Over 20 & 13 & 7,3 \\
\hline \multicolumn{3}{|l|}{ Province } \\
\hline Eastern Province & 60 & 33,7 \\
\hline Western Province & 59 & 33,1 \\
\hline Central Province & 53 & 29,8 \\
\hline Other & 6 & 3,4 \\
\hline
\end{tabular}

\section{Satisfaction levels of displaced employees}

Outsourcing of IS function has often led to job displacement. This is what is revealed in most pervious research. To test the situation in Saudi Arabia, a question was asked if respondents lost their job due to outsourcing. Contrary to most previous studies, only about 5 per cent indicated that outsourcing led to job displacement (See Table 2). When further asked, as to the nature of displacement, almost all of them indicated that it was a transfer.

ANOVA test were conducted to find the satisfaction levels between displaced and non-displaced employees. The test did not reveal any significant difference between the two groups of employees. This suggests that there is no difference between the displaced and non-displaced employee relating to job satisfaction exist as the result of IT outsourcing.

\section{Feelings towards outsourcing}

Respondents were asked to indicate their feelings when going through the outsourcing process. Forty one per cent of the respondent had a positive feeling, while only about twelve per cent report a negative feeling.

To test the attitude of employees towards the word outsourcing itself, respondents were asked to mention the word below that closely matches their feelings when the word outsourcing is mentioned. From Table 3 it can be seen that over half of the respondents a have positive attitude towards outsourcing.

Table 2: Loss of job due to outsourcing

\begin{tabular}{l|c|c}
\hline & Frequency & Per cent \\
\hline Displaced & 10 & 5,6 \\
\hline Not Displaced & 168 & 94,4 \\
\hline Total & 178 & 100 \\
\hline
\end{tabular}


Table 3: Employees feelings towards outsourcing

\begin{tabular}{l|c|c|c|r}
\hline \multirow{2}{*}{} & \multicolumn{2}{|c|}{ During Outsourcing Process } & \multicolumn{2}{c}{ When word 'Outsourcing' is mentioned } \\
\cline { 2 - 5 } & Frequency & Per cent & Frequency & Percent \\
\hline Positive & 73 & 41 & 90 & 50,6 \\
\hline Neutral & 84 & 47,2 & 83 & 46,6 \\
\hline Negative & 21 & 11,8 & 5 & 2,8 \\
\hline Total & 178 & 100 & 178 & 100 \\
\hline
\end{tabular}

\section{Study findings}

\section{Individual factors affecting outsourcing}

Respondents were asked to indicate the individual factors affecting outsourcing to five statements relating to career opportunities, compensation, job security, job satisfaction, and skill requirements. The responses are provided in Table 4. The responses have been overwhelmingly towards agree or strongly agree for all the five statements.

From the mean scores, it can be inferred that respondents have a stronger degree of agreement to all the five statements. Outsourcing of IS function seem to give more opportunities for career development. Respondents do not see much threat to job security.

\section{Organizational factors affecting outsourcing}

In the next section, respondents were asked to indicate their impact of organizational factors on outsourcing decision. Responses are provided in Table 5. Overall, there is a strong degree of agreement that organizational factors in Saudi Arabia have largely contributed to a positive attitude of employees towards IT outsourcing.

\section{Factors relating to vendor company affecting outsourcing}

Respondents also agree that vendors in Saudi Arabia have been committed to ensure customer satisfaction, success of employers and welfare of IS system professionals. Outsourcing has also proved to be playing a positive role in advancement of career advancement (See Table 6).

\section{Study implications}

As the findings suggest, outsourcing in Saudi Arabia has not led to displacement of IT employees, which is contrary to popular belief. By ensuring employees do not lose their jobs and instead transferred to outsourcing firms, morale of employees is attempted to be retained. One explanation for this is that a large number of professionals in the IT/IS functions are expatriate employees on contractual basis. Transferring rather than terminating their services is a better option, as procedures involve $d$ in recruiting new professionals can be lengthy.

As there is no fear of job loss, the feeling of employees towards outsourcing is between positive and neutral. About 50 per cent of the employees reported that they had a positive feeling when the word outsourcing was mentioned.
However, this percentage has come down to 41 , as the actual process of outsourcing took place. The opinion of neutrality has remained consistent at these stages (47 per cent). However, there is a slight increase in the negative feeling by employees during the outsourcing process. These findings are contrary to findings conducted in studies in the 1990s, which generally reported negative employee feelings towards IT outsourcing (example, Khosrowpour et al., 1996; YongKi \& Shin Min, 2005).

IT employees generally perceive a positive affect due to IT outsourcing. Over 80 per cent of respondents either strongly agree or agree that IT outsourcing leads to better career opportunities. About 75 per cent of respondents say that it leads to better compensation packages for them. There is also an agreement on better job security and job satisfaction with being in the outsourcing firm. This implies that there is not much of a resistance from IT employees on a management decision to outsource IT functions.

Questions were also designed to capture respondent's perceptions on what they felt to work for an information technology firm as compared to a non-information technology firm. A majority of the respondents agreed to a positive influence of IT outsourcing. Respondents felt that their IT skills were enhanced with the outsourcing venture; their career objective could be further met; and maintained a positive attitude outsourcing

Another finding of this study is that employees also have a favourable attitude about the effectiveness of the vendor companies and are also satisfied with communication flow between them and the vendor companies. This is generally in contrast to most previous studies.. This is also a positive trigger for firms to consider outsourcing.

Overall, an important revelation of this study is that employees do not feel negatively impacted by outsourcing of the IT activities of their organizations. This is in contrast to most previous studies. Perhaps, the reason for this could be the nature of employment structure in Saudi Arabia. Although unemployment levels are high, there is a shortage of skilled IS professionals. As said earlier, firms in Saudi Arabia largely rely on expatriate workforce for IS jobs to a large extent. Due to shortage of skilled labour force, the threat to job loss is rather limited. Absence of a fear of job loss, also gives a feeling of security and a positive attitude towards outsourcing. Management of organizations in Saudi Arabia, do not meet with any resistance from employees, in fact the attitude is positive, and this should be seen as a favourable factor in decision to outsource. 
Table 4: Individual factors affecting outsourcing decision

\begin{tabular}{|c|c|c|c|c|c|c|c|}
\hline & $\begin{array}{l}\text { Strongly } \\
\text { agree }\end{array}$ & Agree & Neutral & Disagree & $\begin{array}{l}\text { Strongly } \\
\text { Disagree }\end{array}$ & Means & SD \\
\hline Better Career opportunities in IT firms. & $54(30,3)$ & $87(48,9)$ & $33(18,5)$ & $4(2,2)$ & 0 & 1,93 & 0,76 \\
\hline $\begin{array}{l}\text { Better compensation opportunities in IT } \\
\text { firms. }\end{array}$ & $23(12,9)$ & $92(51,7)$ & $49(27,5)$ & $14(7,9)$ & 0 & 2,03 & 0,79 \\
\hline Better job security in IT firms. & $20(11,2)$ & $63(35,4)$ & $71(39,9)$ & $22(12,4)$ & $2(1,1)$ & 2,57 & 0,89 \\
\hline Better job satisfaction in IT firms. & $20(11,2)$ & $62(34,8)$ & $79(44,4)$ & $17(9,6)$ & 0 & 2,52 & 0,82 \\
\hline My job functions is more suited to IT firms & $15(8,4)$ & $79(44,4)$ & $66(37,1)$ & $19(10,1)$ & 0 & 2,49 & 0,79 \\
\hline
\end{tabular}

Notes: Mean scores based on a five-point scale ranging from $1=$ Strongly Agree to $5=$ Strongly Disagree.

Table 5: Organizational factors affecting outsourcing decision

\begin{tabular}{|c|c|c|c|c|c|c|c|}
\hline & $\begin{array}{l}\text { Strongly } \\
\text { agree }\end{array}$ & Agree & Neutral & Disagree & $\begin{array}{l}\text { Strongly } \\
\text { Disagree }\end{array}$ & Means & SD \\
\hline $\begin{array}{l}\text { My IS skills are enhanced at the onset of } \\
\text { the outsourcing venture }\end{array}$ & $36(20,2)$ & $100(56,2)$ & $34(19,1)$ & $6(3,4)$ & $2(1,1)$ & 2,09 & 0,79 \\
\hline $\begin{array}{l}\text { Helping me identify further career } \\
\text { objectives }\end{array}$ & $14(7,9)$ & $83(46,6)$ & $67(37,6)$ & $10(5,6)$ & $4(2,2)$ & 2,48 & 0,81 \\
\hline $\begin{array}{l}\text { Welfare of IS system professional key } \\
\text { factor in management of contracting } \\
\text { company }\end{array}$ & $21(11,8)$ & $71(39,9)$ & $65(36,5)$ & $19(10,7)$ & $176(98,9)$ & 2,47 & 0,84 \\
\hline Maintain positive attitude about success & $24(13,5)$ & $102(57,3)$ & $45(25,3)$ & $7(3,9)$ & 0 & 2,2 & 0,71 \\
\hline $\begin{array}{l}\text { Communication flow since onset was } \\
\text { adequate to keep positive attitude }\end{array}$ & $11(6,2)$ & $88(49,4)$ & $67(37,6)$ & $12(6,7)$ & 0 & 2,45 & 0,71 \\
\hline $\begin{array}{l}\text { Outsourcing venture proved positive in } \\
\text { advancing my career }\end{array}$ & $25(14)$ & $82(46,1)$ & $54(30,3)$ & $10(5,6)$ & $7(3,9)$ & 2,39 & 0,93 \\
\hline
\end{tabular}

Notes: Mean scores based on a five-point scale ranging from $1=$ Strongly Agree to $5=$ Strongly Disagree

Table 6: Vendor company and factors affecting outsourcing decision

\begin{tabular}{|c|c|c|c|c|c|c|c|}
\hline & $\begin{array}{c}\text { Strongly } \\
\text { agree }\end{array}$ & Agree & Neutral & Disagree & $\begin{array}{l}\text { Strongly } \\
\text { Disagree }\end{array}$ & Means & SD \\
\hline Committed to success of customer & $26(14,6)$ & $65(36,5)$ & $74(41,6)$ & $11(6,2)$ & $2(1,1)$ & 2,43 & 0,86 \\
\hline Committed to success of employer & $30(16,9)$ & $101(56,7)$ & $42(23,6)$ & $5(2,8)$ & - & 2,12 & 0,71 \\
\hline $\begin{array}{l}\text { Welfare of IS system professional key } \\
\text { factor in outsourcing company }\end{array}$ & $31(17,4)$ & $66(37,1)$ & $70(39,3)$ & $11(6,2)$ & - & 2,34 & 0,84 \\
\hline $\begin{array}{l}\text { Outsourcing venture proved positive in } \\
\text { advancing my career }\end{array}$ & $25(14,0)$ & $82(46,1)$ & $54(30,3)$ & $10(5,6)$ & $7(3,9)$ & 2,39 & 0,93 \\
\hline
\end{tabular}

Notes: Mean scores based on a five-point scale ranging from 1 = Strongly Agree to 5 = Strongly Disagree

This finding of this lends support to a previous that found outsourced employees maintain their commitment to the host company and that this commitment was stronger than their commitment to the new employer of (Kessler et al., 1999). The possible implication of this finding of the study is that firms outsourcing their IT function in the Saudi Arabia should not be worried about any dampening of loyalty of their employees due to an IT outsourcing decision.

\section{Conclusions}

The study objectives were investigated with 178 responses administered to employees across the three provinces in Saudi Arabia and spanning diverse industries. This study is one of the first studies to asses the employees perceptive of IT outsourcing in Saudi Arabia. Thus, the findings of the study add to the dearth of literature on outsourcing in general, and IT outsourcing in particular in developing countries like Saudi Arabia. We believe that there is a great potential for further enhancing the use of IT outsourcing services for a number of reasons. Historically, the trend among firms in Saudi Arabia has been to outsource business functions. Secondly, Saudi Arabia had made significant strides in industrial development. More opportunities for IT service providers are certain to emerge with the economy entering a new phase of development since its joining the World Trade Organization.

The study findings also show employees have favourable attitude in general on the IT outsourcing in Saudi Arabia. Specifically, it was found that employees in Saudi Arabia have favourable attitude on their job security as result of IT outsourcing, effectiveness of outsourcing and appropriateness of communication between outsourcing and outsourced companies.

However, like any other study of its kind, this study also suffers from some limitations. The limited sample size is one among them. More empirical work, with larger samples, is needed to generalize findings. The results of the study must therefore be treated with caution. While this study provides a comprehensive comparative analysis of the employee perspective of IT outsourcing in Saudi Arabia, there are several worthwhile directions for further work on this topic. One area is to examine the trends over time. It is 
suggested that similar studies be conducted in future to provide insights into the trends and direction of the changing employee perspectives due to outsourcing.

\section{Acknowledgement}

The author acknowledges King Fahd University of Petroleum and Minerals, Saudi Arabia for the facilities and financial support provided to complete this this research.

\section{References}

Adeleye, B.C., Annansingh, F. \& Nunes, M. B. 2004. 'Risk management practices in IS outsourcing: An investigation into commercial banks in Nigeria', International Journal of Information Management 24(2):167-180.

Aubert, B., Patry, M. \& Rivard, S. 2004. 'A transaction cost model of IT outsourcing', Information and Management, 41(7):921-32.

Aundhe, M. D. \& Mathew, S. K. 2009. 'Risks in offshore IT outsourcing: A service provider perspective', European Management Journal, 27:418-428.

Barthelemy, J. \& Geyer, D. 2004. 'An empirical investigation of IT outsourcing versus quasi-outsourcing in France and Germany', Journal of Information and Management, 42:533-542.

Beasley, M., Bradford, M. \& Pagach, D. 2004. 'Outsourcing? At your own risk', Strategic Finance, 86(1):22-9.

Beasley, M., Bradford, M. \& Dehning. B. 2009. 'The value impact of strategic intent on firms engaged in information systems outsourcing', International Journal of Accounting Information Systems, 10:79-96.

Beaumont, N. \& Costa, C. 2002. 'Information technology outsourcing in Australia', Information Resources Management Journal, 15(3): 14-31.

Benson, J. 1998. 'Dual commitment: Contract workers in Australian manufacturing enterprises', Journal of Management Studies, 35(3): 355-75.

Bhattacharjee, S., Tung, Y.A. \& Pathak, B. 2004. 'Author experiences with the IS journal review process', Communications of the Association for Information Systems 13:629-653.

Cheon, M.J., Grover, V. \& Teng, J.T.C. 1995. 'Theoretical perspective on the outsourcing of information systems', Journal of Technology Information, 10: 209-19.

Costa, C. 2001. 'Information technology outsourcing in Australia: A literature review', Information Management \& Computer Security, 9(5): 213-224.

Due, R.T. 1992. 'The real costs of outsourcing,' Information Systems Management, 9(1): 78-81.
Geibstein, E. 2002. 'Outsourcing'. In Bidgoli, H. et al. (Eds.). Encyclopaedia of information systems, pp. 428-430.

Gonzales, R., Gasco, J. \& Llopis, J. 2006. 'Information systems outsourcing: A literature analysis', Journal of Information and Management, 43:821:834.

Grover, V., Cheon, M.J., \& Teng, J. T. 1994. 'A descriptive study on the outsourcing of information systems functions', Information \& Management: 27: 33, 44.

Han, H., Lee, J. \& Seo, Y. 2008. 'Analyzing the impact of a firm's capability on outsourcing success: A process perspective', Information and Management, 45(1):31-42.

Kern, T., Kreijger, J. \& Willcocks, L. 2002. 'Exploring ASP as sourcing strategy: Theoretical perspectives, propositions for practice', Journal of Strategic Information Systems, 11(2): 53-177.

Kessler, I., Coyle-Shapiro, J. \& Purcell, J. 1999. 'Outsourcing and the employee perspective', Human Resource Management Journal, 9: 5-19.

Khosrowpour, M., Subramanian, G.H., Gunderman, J. \& Saber, A. 1996. 'Managing information technology with outsourcing: an assessment of employee perceptions', Journal of Applied Research, 12(3): 85-96.

Lacity, M., Khan, S. \& Willcocks, L. 2009. 'A review of the IT outsourcing literature: Insights for practice', Journal of Strategic Information Systems, 18:130-146.

Lacity, M.C. 1992. 'An interpretive investigation of the information outsourcing phenomenon'. Unpublished doctoral dissertation, University of Houston, Houston, TX.

Lacity, M.C. \& Hirschheim, R. 1993. 'Implementing information systems outsourcing: Key issues and experiences of an early adopter', Journal of General Management, 19(1): 17-31.

Lacity, M.C. \& Willcocks, L.P. 1998. 'An empirical investigation of information technology sourcing practices: lessons from experience', MIS Quarterly, 22(3): 363-408.

Larribee, J.F. \& Michaels-Barr, L. 1994. 'Dealing with personnel concerns in outsourcing, Journal of Systems Management, January: 6 -10.

Lee, J. 2001. 'The impact of knowledge sharing, organizational capability and partnership quality on IS outsourcing success', Information and Management, 38(5):323-35.

Logan, M., Faught, K. \& Ganster, D. 2004. 'Outsourcing a satisfied and committed workforce: A trucking industry case study', International Journal of Human Resource Management, 15(1): 147-62. 
Loh, L. \& Venkatraman, N. 1992. 'Diffusion of information technology outsourcing: Influence sources and the Kodak effect,' Information Systems Research, 3: 334-58.

Mahmood, M.A., Hall, L. \& Swanberg, D.L. 2001. 'Factors affecting information technology usage: A meta-analysis of the empirical literature', Journal of Organizational Computing and Electronic Commerce, 11(2):107-130.

Mann, C. 2003. 'Globalization of IT services and white collar jobs: The next wave of productivity growth', International Economics Policy Briefs: PB03-11, Publisher, Institute for International Economics Washington, DC.

Mason, T. 1990. Perot. Homewood, IL: Dow Jones-Irwin.

McFarlan, F.W. \& Nolan, R.L. 1995, 'How to manage an IT outsourcing alliance', Sloan Management Review, 36: 9-22.

Oh, W., Gallivan, M. \& Kim, J. 2006. 'Exploring the market's perception of the transactional risks of IT outsourcing announcements', Journal of Management Information Systems, 22(4):271-304.

Sengupta, K. \& Zviran, M. 1997. 'Measuring user satisfaction an outsourcing environment', IEEE transactions on Engineering Management, 44(4):414-21.

Smith, M.A \& Kumar, R.L. 2004. 'A theory of application service provider (ASP) use from a client perspective', Information and Management 41(8):977-1002.

Sohail, M.S., \& Al-Abdali, O., 2005. 'The usage of third party logistics in Saudi Arabia: Current position and future prospects', International Journal of Physical Distribution \& Logistics Management, 35(9): 637-653.

Sohal, A. S. \& Ng, L. 1998. 'The role and impact of information technology in Australian businesses,' Journal of Information Technology, 13(3): 201-17.

Willcocks, L.P., Fitzgerald, G. \& Fenny, D. 1995. 'Outsourcing IT: the strategic implications', Long Range Planning, 28(5): 59-70.

Yang, C., \& Huang J. 2000. 'A decision model for IS outsourcing', International Journal of Information Management, 20:225-39.

YongKi, Y. \& Shin Min, K. 2005. 'An evaluation system for IT outsourcing customer satisfaction using the analysis', Journal of Global Information Management, 13: 55-78. 
